\title{
Assessment of Sulfate Sources under Cold Conditions as a Geochemical Proxy for the Origin of Sulfates in the Circumpolar Dunes on Mars
}

\author{
Anna Szynkiewicz ${ }^{1, *}$ and Janice L. Bishop ${ }^{2}$ \\ 1 Department of Earth and Planetary Sciences, University of Tennessee, Knoxville, TN 37916, USA \\ 2 Carl Sagan Center, SETI Institute, Mountain View, CA 94043, USA; jbishop@seti.org \\ * Correspondence: aszynkie@utk.edu
}

Citation: Szynkiewicz, A.; Bishop, J.L. Assessment of Sulfate Sources under Cold Conditions as a Geochemical Proxy for the Origin of Sulfates in the Circumpolar Dunes on Mars. Minerals 2021, 11, 507. https:// doi.org/10.3390/min11050507

Academic Editors: Yasuhito Sekine, Elizabeth B. Rampe and

Keisuke Fukushi

Received: 11 February 2021

Accepted: 8 May 2021

Published: 11 May 2021

Publisher's Note: MDPI stays neutral with regard to jurisdictional claims in published maps and institutional affiliations.

Copyright: (c) 2021 by the authors. Licensee MDPI, Basel, Switzerland. This article is an open access article distributed under the terms and conditions of the Creative Commons Attribution (CC BY) license (https:// creativecommons.org/licenses/by/ $4.0 /)$.

\begin{abstract}
Determining aqueous sulfate sources in terrestrial cold environments can provide an insight into the surface hydrological conditions and sulfur cycle on Mars. In this study, we analyzed sulfur and oxygen isotope compositions of secondary sulfate salts (e.g., gypsum, thenardite) in the surficial sediments and soils of the McMurdo Dry Valleys (MDV), Antarctica to determine contributions of sulfate from bedrock chemical weathering and atmospheric deposition under persistent dry polar conditions. The sulfate showed wider variation of $\delta^{34} \mathrm{~S}(+15.8 \%$ o to $+32.5 \%$ o) compared to smaller ranges of $\delta^{18} \mathrm{O}\left(-8.9 \%\right.$ to $-4.1 \%$ ). In contrast, the $\delta^{34} \mathrm{~S}$ of bedrock sulfide showed significantly lower and consistent values across the studied area ( $-0.6 \%$ to $+3.3 \%$ ). Based on the $\delta^{34} \mathrm{~S}$ trends, sulfide weathering may contribute up to $20-50 \%$ of secondary sulfate salts in the MDV. While the remaining $50-80 \%$ of sulfate inputs may originate from atmospheric deposition (e.g., sea aerosols, dimethulsulfide oxidation), the subglacial brines derived by relicts of seawater and/or lake/pond water influenced by microbial sulfate reduction could also be important sulfate endmembers particularly in the Antarctic lowland thaw zones. Additional field observations of frost, ponding water, and thin gypsum crusts on the terrestrial gypsum dunes at White Sands supports reactivity of gypsum on the surface of these dunes during cold winter conditions. Combined with our improved geochemical model of the sulfur cycle for cold Antarctic settings, we propose that transient liquid water or frost was available in near-surface environments at the time of gypsum formation in the north polar region on Mars. Ice and/or water interaction with basaltic sand of the basal unit (paleo-erg) would have enhanced leaching of sulfate from both sulfide oxidation and atmospheric deposition and resulted in formation of secondary gypsum salts.
\end{abstract}

Keywords: sulfate; isotopes; polar; Earth; Mars

\section{Introduction}

Sulfate minerals show a wide spatial distribution around the north polar ice cap on Mars. The highest concentrations of gypsum have been measured within the Olympia Undae dune field, mainly along dune crests, but spectral signatures of gypsum can be traced for thousands of kilometers within the circumpolar basaltic dune fields and sand layers (basal unit) underlying the ice cap [1-3]. Various geochemical models have been proposed for the origin of gypsum including atmospheric deposition of volcanic aerosols [4], sulfide weathering within the dunes by infiltrating melt waters [5], and erosion of gypsum-rich sand layers underlying the ice cap [2,3]. However, none of these models have strong support from terrestrial analog studies. One of the difficulties addressing the origin of sulfate in the north polar deposits is limited research and no clear consensus on aqueous sulfate sources in terrestrial polar environments. While sulfide weathering is proposed to be the primary sulfate source in Arctic glacial and subglacial systems [6], an atmospheric origin is favored for sulfate forming under dry polar conditions in Antarctica [7-9]. An additional difficulty is that previous geochemical models for Mars $[2,4,5,10]$ are mainly 
based on a single-sulfate-source approach, overlooking the fact that multiple sources of aqueous sulfate are usually activated by the water cycle on the planet's surface [11].

The gypsum-enriched circumpolar dune fields around the north polar ice cap on Mars are unique in our solar system and no place exists on Earth to directly compare with this unusual Martian phenomenon. While we recognize that the sulfate origin will remain speculative without in situ measurements for the Martian circumpolar dunes, we propose that some valid assessments on the sulfate origin can nevertheless be made using geochemical proxies for the sulfur cycle in terrestrial environments. This is because formation of sulfate minerals is primarily controlled by the hydrological cycle remobilizing three main sulfur endmembers derived from (i) volcanic activity, (ii) weathering of bedrock minerals (sulfides, sulfates), and (iii) atmospheric deposition [11-13]. Antarctica is an excellent geochemical analog for the Martian sulfates of the north polar region because of the prevailing dry and cold conditions for thousands to millions of years [14] and abundant accumulations of secondary sulfate minerals (e.g., gypsum, thenardite, mirabilte) in surficial deposits [15-17]. Additionally, the terrestrial gypsum dunes such as in White Sands National Monument undergo seasonal climatic cycles and hydrological processes that include cold conditions (sometimes below freezing) during the winter. Therefore, some of the morphological features related to frost/ice accumulation and occasional groundwater rise can be used to validate the transport of aqueous sulfate within the dune field under cold climatic conditions that is relevant for determining the origin of gypsum in the north polar region on Mars.

Here, we present a new dataset on the sulfur $\left(\delta^{34} \mathrm{~S}\right)$ and oxygen $\left(\delta^{18} \mathrm{O}\right)$ isotope compositions of secondary sulfate salts present in surficial deposits of the South Fork in Wright Valley, one of the glacial catchments in the McMurdo Dry Valleys, Antarctica (Figure 1). Our further comparisons with previous isotopic studies allow for better identification and quantification of sulfate sources in dry polar settings. Additionally, we present new field observations of geomorphological features in the White Sands gypsum dune field formed as a result of water cycling and ice accumulation during cold winter conditions. Consequently, we use these combined datasets to propose a new conceptual model of geochemical and aqueous processes that might have led to widespread formation of sulfate for gypsum precipitation in the north polar deposits on Mars.
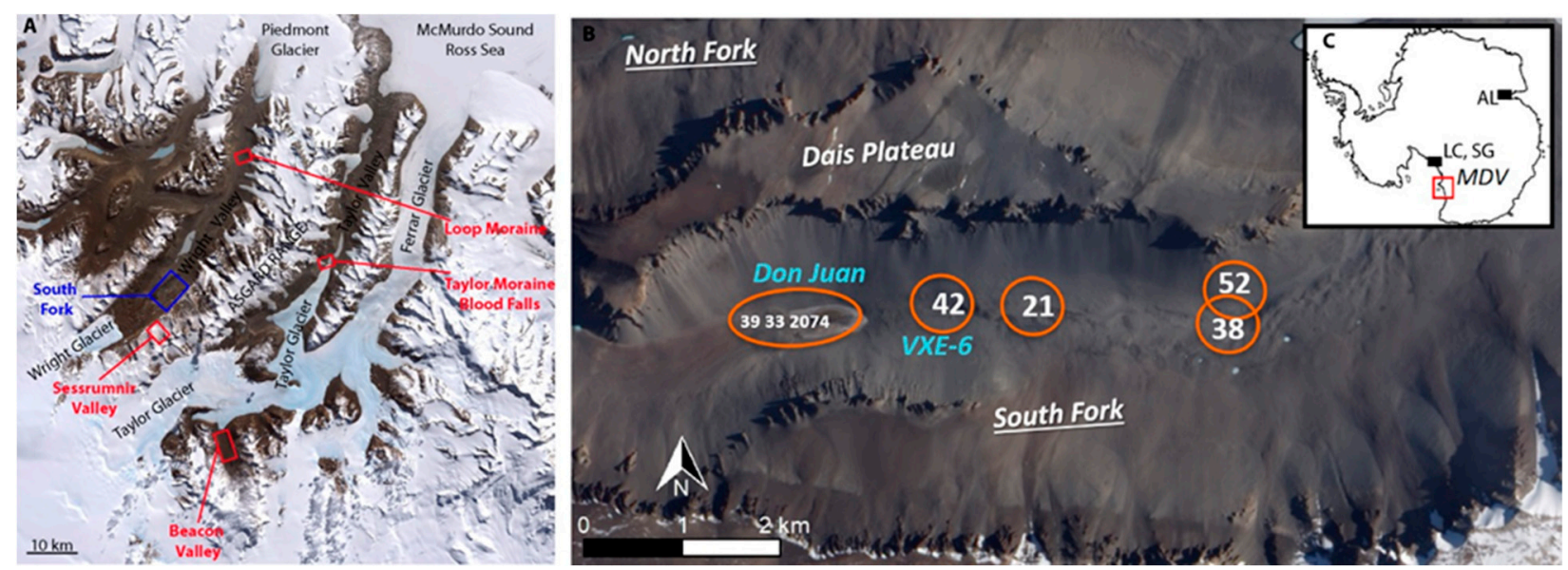

Figure 1. Location maps of sampling sites in Antarctica. (A) Location of the South Fork catchment (blue) in the McMurdo Dry Valleys compared to other sampling sites for the sediments (red) studied by Bao and Marchant [7]. Image credit: Landsat 7. (B) Locations of seven sampling sites in the South Fork catchment analyzed in our study. Image credit: Google Earth. (C) Regional map of Antarctica showing approximate locations of the McMurdo Dry Valleys (MDV), Lewis Cliff (LC), Shackleton Glacier (SG), and Ace Lake (AL). 


\section{Environmental Settings of Terrestrial Analogs}

\subsection{Analog 1-South Fork of Wright Valley, Antarctica}

South Fork is a small glacial catchment located in the Upper Wright Valley of the McMurdo Dry Valleys (MDV) in Eastern Antarctica (Figure 1). Major rock formations outcropping on the surface are sedimentary formations of the Beacon Supergroup and basaltic lavas and dolerite sills of the Ferrar Group [14,18,19]. The Beacon Supergroup is of Early Devonian to Late Triassic age ( 400-200 Ma), formed when Antarctica was a part of the supercontinent Gondwana. These sedimentary rocks are mainly composed of sandstone with layers of coal, limestone, conglomerate, and shale. The sandstone of the Beacon Supergroup has documented occurrences of pyrite-rich concretions [14]. During the Gondwana break-up ( 180 Ma), the sedimentary rocks of the Beacon Supergroup were intruded by erupting basaltic lava and dolerite sills of the Ferrar Group. The Beacon Supergroup and Ferrar Basalt/Dolerite are underlined by Precambrian basement rocks comprised of sedimentary and volcanic rocks that were intensely folded, regionally metamorphosed, and intruded by granitic rocks during the Ross Orogeny (530-470 Ma). There are also reports of limited sulfide occurrences associated with basement rocks [14].

Glacial activity led to formation of moraine and till deposits across the MDV that contain clasts composed of Ferrar Dolerite and Beacon Supergroup rocks that were eroded under the Antarctic ice moving from the center of the continent toward the coast [14]. In some locations, the till matrix contains detrital pyrite that likely comes from erosion of the Beacon Supergroup and/or Ferrar Dolerite. In MDV, major glacial activity likely ceased by $\sim 3-4 \mathrm{Ma}$ ago in the valley bottoms, but persistent cold-desert, ice-free, and hyper-arid environmental conditions have existed in this region for up to $\sim 8-11 \mathrm{Ma}$ (since the Miocene) in the upland valleys [18-20]. This is inferred based on unaltered lava flows and ash deposits of the McMurdo Volcanic Group that cover some of the glacial tills and moraines. Elevated secondary sulfate salts (gypsum, thenardite, etc.) are mixed with detrital grains of glacial sediments. These salts mainly occur in the Miocene glacial tills $(\sim 8-15 \mathrm{Ma})$ and in valley floor moraine deposits $(\sim 3-4 \mathrm{Ma})$, and are believed to be primarily sourced by atmospheric deposition (sea aerosols, dimethylsulfide, volcanic emissions, etc.) with smaller contributions from bedrock weathering such as pyrite oxidation [7]. The timing of their formations, however, has not yet been determined [7].

The MDV analog site allows for testing previous geochemical models proposing that sulfide weathering [5] and atmospheric deposition [4] contributed to gypsum formation in the Martian north polar region. Although the MDV have some rock units (e.g., Paleozoic sedimentary rocks of the Beacon Supergroup [14]) that differ from the basalt-dominated Martian north pole surface, the MDV analog site meets important conceptual conditions to accurately assess and quantify formation processes of secondary sulfate salts that are relevant for a cold Mars. Bedrock mineralogy is simply not the driving force behind the sulfate budget of hydrologic systems (e.g., [12,13]). Similar types of sulfide minerals (e.g., pyrite) have been commonly reported for both sedimentary and basaltic rocks (e.g., [21]). Despite the fact that different sulfate sources have been contributing to Earth's atmosphere (e.g., volcanic, oceanic, anthropogenic) than on Mars (mainly volcanic), this does not change the manner of their ultimate deposition on land. Because of quick mixing, sulfates from various atmospheric sources are thoroughly mixed in air and subsequently incorporated into rain/snow precipitation on Earth. Therefore, valuable comparisons can be made for Mars even under the assumption that mainly past volcanic emissions have likely contributed sulfates to the Martian atmosphere [10].

\subsection{Analog 2-White Sands, New Mexico}

White Sands gypsum dunes are located in Southern-central New Mexico of the United States, in the closed-drainage Tularosa Basin that formed by extensional tectonics in the Rio Grande Rift. Evolution of the Rio Grande Rift during the last 30-3 Ma resulted in formation of topographically closed basins, including the Tularosa Basin, which filled with latitudinally variable detrital and evaporitic lake sediments [22,23]. During the last 
glacial maximum in the late Pleistocene, the climate was distinctively colder and wetter than current semi-arid conditions in this area. Topographic closure favored formation of temporary, highly mineralized lakes in which thick layers of evaporitic precipitates including gypsum and carbonate were deposited as the climate shifted to increasing aridity during the Holocene [22,23]. The White Sands region contains the largest gypsum dunes in the Rio Grande Rift, which formed as a result of wind erosion of lake evaporitic sediments in at least two or three episodes of intensified aridity during the last 7000 years [22]. Dissolution of local Permian evaporites of marine origin is the main source of sulfate for gypsum in evaporative lake deposits and the White Sands dunes [24,25]. Early diagenesis of gypsum dunes appears to be active and, notably, to be taking place in close to the dune surface. Activation of early diagenesis is related to interaction of gypsum grains with the water table and occurs in the capillary fringe and phreatic zones [26]. Seasonal downward infiltration of meteoric precipitation causes cementation in the upper parts of dune because gypsum is a readily soluble mineral. Investigation of gypsum and minor occurrences of quartz and dolomite at this site indicated that gypsum is concentrated in the dunes because it is more readily produced and transported than other minerals [27].

It should be kept in mind that the primary source of sulfate for the White Sands gypsum cannot be directly compared to the Martian north polar dunes because the sulfate-rich sedimentary rocks of marine origin have not been detected on Mars. However, the White Sands analog is valuable for assessing the role of hydrological processes under cold winter conditions in formation of secondary gypsum deposits during dune field evolution. Consequently, the previous models focused on secondary aqueous and weathering processes on Mars $[2,3,5]$ can be tested.

\section{Methods}

\subsection{Field Sample Collection in South Fork of Wright Valley, Antarctica}

Our samples were acquired in 1980 [15] and represent surface and near-surface sediments and soils collected in or near dry, shallow groundwater-fed transient ponds present along the South Fork of Wright Valley (Table 1). The samples in this study were taken from $\sim 1 \mathrm{~m}$ deep pits excavated in the upper till and/or pond deposits. Bulk samples were collected at different depths from the walls of the pit into zip-lock Teflon bags using a stainless steel spatula and stored at $-40{ }^{\circ} \mathrm{C}$ during transport to the United States $[15,28]$. Don Juan Pond (DJP) is the largest pond and contained moist material and some brine in 1980. It is situated at the lowest elevation (Figure 1) along the South Fork. The sediment sample at site 2074 was collected at the center of DJP. Additional soil pits were dug near DJP. The site 33 was located about halfway between the center of DJP and the southern edge of the pond, and the site 39 was located about $300 \mathrm{~m}$ west of DJP. The VXE- 6 pond near site 42 , located about $500 \mathrm{~m}$ east of DJP, was dry at the time of sampling but showed evidence of former evaporite activity. The site 52 was about $2 \mathrm{~km}$ east of the VXE-6 pond along the South Fork.

Portions of these collected samples were crushed to $<125 \mu \mathrm{m}$ in order to homogenize the samples for initial chemical and mineralogical analyses by Gibson et al. [15]. Afterward, the dry samples were stored in plastic bags at room temperature. Prior to $\delta^{34} \mathrm{~S}$ and $\delta^{18} \mathrm{O}$ analyses (our study), the samples from various depths of 0-24 $\mathrm{cm}$ (mainly active zone above permafrost [15]) were ground to fine-grained fraction using a zirconium pestle mortar. 
Table 1. Description of sediment and soil samples from South Fork of Wright Valley, Antarctica and their isotope compositions of sulfur-bearing mineral phases determined using the sulfur sequential extraction method. b.d.-below detection.

\begin{tabular}{|c|c|c|c|c|c|c|c|c|}
\hline \multirow{2}{*}{$\begin{array}{c}\text { Sample } \\
\text { ID }\end{array}$} & \multirow{2}{*}{ Location } & \multirow{2}{*}{ Depth } & \multirow{2}{*}{ Sample Character } & \multicolumn{3}{|c|}{ Acid-Soluble $\mathrm{SO}_{4}{ }^{2-}$} & \multicolumn{2}{|c|}{ Cr-Reducible Sulfide } \\
\hline & & & & wt $\%$ S & $\delta^{34} \mathrm{~S}(\%)$ & $\delta^{18} \mathrm{O}(\%)$ & $w t \% S$ & $\delta^{34} S(\%)$ \\
\hline JB1100 & VXE-6 pond, near site 42 & $0-1 \mathrm{~cm}$ & $\tan$ soil & 0.057 & +16.7 & -8.7 & $<0.01$ & +1.0 \\
\hline JB1101 & VXE-6 pond, near site 42 & $1-4 \mathrm{~cm}$ & $\tan$ soil & 0.011 & +16.4 & -8.4 & $<0.01$ & b.d. \\
\hline JB1102 & VXE-6 pond, near site 42 & $4-7 \mathrm{~cm}$ & reddish soil & 0.286 & +15.8 & -7.2 & b.d. & b.d. \\
\hline JB1103 & VXE-6 pond, near site 42 & $8-10 \mathrm{~cm}$ & beige sediment & 0.900 & +16.6 & -8.9 & $<0.01$ & +3.3 \\
\hline JB1104 & VXE-6 pond, near site 42 & $12-15 \mathrm{~cm}$ & beige sediment & 0.562 & +16.2 & -7.4 & b.d. & b.d. \\
\hline JB1105 & VXE-6 pond, near site 42 & $20-24 \mathrm{~cm}$ & beige sediment & 0.070 & +15.9 & -7.9 & $<0.01$ & +2.6 \\
\hline JB1108 & dried pond near site 52 & $2-4 \mathrm{~cm}$ & - & 0.854 & +23.4 & -5.6 & $<0.01$ & -0.2 \\
\hline JB1109 & dried pond near site 52 & $4-8 \mathrm{~cm}$ & - & 0.664 & +17.8 & -6.6 & $<0.01$ & +0.1 \\
\hline JB1111 & outer edge of pond near site 38 & $0-1 \mathrm{~cm}$ & reddish soil & 0.885 & +17.7 & -6.1 & $<0.01$ & -0.6 \\
\hline JB1125 & center of DJP, near site 2074 & $0-10 \mathrm{~cm}$ & - & 0.273 & +31.5 & -5.4 & b.d. & b.d. \\
\hline JB1129 & southern part of DJP, near site 33 & $0-1 \mathrm{~cm}$ & - & 0.020 & +32.5 & -5.3 & $<0.01$ & +3.3 \\
\hline JB1130 & southern part of DJP, near site 33 & $3-4 \mathrm{~cm}$ & - & 0.173 & +31.9 & -5.5 & $<0.01$ & +1.1 \\
\hline JB1131 & southern part of DJP, near site 33 & $8-10 \mathrm{~cm}$ & - & 1.000 & +32.0 & -5.9 & $<0.01$ & +1.1 \\
\hline JB1132 & southern part of DJP, near site 33 & $12-14 \mathrm{~cm}$ & - & 0.170 & +32.0 & -4.2 & $<0.01$ & +3.0 \\
\hline JB1133 & southern part of DJP, near site 33 & $16-20 \mathrm{~cm}$ & - & b.d. & b.d. & b.d. & $<0.01$ & +0.9 \\
\hline JB1135 & 300 m west of DJP, near site 39 & $2-5 \mathrm{~cm}$ & - & 0.125 & 27.1 & -6.3 & $<0.01$ & -0.5 \\
\hline JB1139 & dried pond near site 21 & $0-1 \mathrm{~cm}$ & reddish brown soil & 0.144 & 17.2 & -7.8 & b.d. & b.d. \\
\hline
\end{tabular}

\subsection{Laboratory Methods for Antarctic Sediments}

The $\delta^{34} \mathrm{~S}$ of oxidized $\left(\mathrm{S}^{6+}\right)$ and reduced $\mathrm{S}$ species $\left(\mathrm{S}^{0}, \mathrm{~S}^{-}, \mathrm{S}^{2-}\right)$ in the studied surface sediments from the South Fork of Wright Valley (Figure 1) were analyzed using a S sequential extraction (SSE) method modified after [24,29]. This method allows for separation of various $\mathrm{S}$ species (acid-soluble $\mathrm{SO}_{4}{ }^{2-}$, elemental $\mathrm{S}$, acid-volatile and chromium-reducible sulfides) for quantitative and $\delta^{34} S$ analyses. SSE was completed in 3 major steps. The first step was the extraction of elemental $S$ from the sediment in a Soxhlet apparatus. At a constant temperature, dichloromethane was dripped into a glass thimble containing the sediment to allow for dissolution of elemental S. The bottom flask contained activated copper granules which reacted with dissolved elemental $S$ and resulted in precipitation of copper sulfides (CuS). Afterwards, in a separate extraction apparatus, copper granules were treated with $30 \mathrm{~mL}$ of $6 \mathrm{~N} \mathrm{HCl}$ in an $\mathrm{O}_{2}$-free atmosphere using $\mathrm{N}_{2}$ gas flowing through the extraction apparatus. The evolved $\mathrm{H}_{2} \mathrm{~S}$ was then precipitated as silver sulfide $\left(\mathrm{Ag}_{2} \mathrm{~S}\right)$. The second step of SSE was the extraction of the acid-volatile sulfide and acid-soluble $\mathrm{SO}_{4}{ }^{2-}$ phases. The sediment processed through Step 1 was treated with $30 \mathrm{~mL}$ of $6 \mathrm{~N} \mathrm{HCl}$ generating $\mathrm{H}_{2} \mathrm{~S}$ gas from decomposition of acid-volatile sulfides that was then precipitated as $\mathrm{Ag}_{2} \mathrm{~S}$. The acid leachate with dissolved $\mathrm{SO}_{4}{ }^{2-}$ was separated from the sediment using a centrifuge. This leachate was filtered and the acid-soluble $\mathrm{SO}_{4}{ }^{2-}$ was precipitated as $\mathrm{BaSO}_{4}$ by adding $2 \mathrm{~mL}$ of $10 \% \mathrm{BaCl}_{2}$ solution. The third and final step of the SSE process was the extraction of chromium-reducible sulfides. Sediment from Step 2 was treated with a mixture of $30 \mathrm{~mL} 12 \mathrm{~N} \mathrm{HCl}$ and $30 \mathrm{~mL}$ of $1 \mathrm{~N} \mathrm{CrCl}_{2} \cdot 6 \mathrm{H}_{2} \mathrm{O}$. Evolved $\mathrm{H}_{2} \mathrm{~S}$ gas generated from decomposition of chromium-reducible sulfides was recovered as $\mathrm{Ag}_{2} \mathrm{~S}$.

The amount of acid-soluble $\mathrm{SO}_{4}{ }^{2-}$ and chromium-reducible sulfides ( $\mathrm{wt} \% \mathrm{~S}$ ) was calculated based on the air-dried masses of $\mathrm{BaSO}_{4}$ and $\mathrm{Ag}_{2} \mathrm{~S}$ relative to the freeze-dried mass of the sample used for extraction. The analytical precision was usually $\pm 0.1 \mathrm{wt} \% \mathrm{~S}$ based on acid-soluble $\mathrm{SO}_{4}{ }^{2-}$ yields in duplicated samples. The $\mathrm{S}$ isotope compositions $\left({ }^{34} \mathrm{~S}\right)$ of $\mathrm{BaSO}_{4}$ and $\mathrm{Ag}_{2} \mathrm{~S}$ were measured using a Costech elemental analyzer (EA) coupled with a Delta Plus $\mathrm{XL}$ isotope ratio mass spectrometer, and $\mathrm{O}$ isotope compositions $\left(\delta^{18} \mathrm{O}\right)$ of $\mathrm{BaSO}_{4}$ were measured using a Thermo Finnigan TC/EA in the Stable Isotope Laboratory, University of Tennessee. For $\delta^{34} \mathrm{~S}$ analysis, $<0.5 \mathrm{mg}$ of $\mathrm{BaSO}_{4} / \mathrm{Ag}_{2} \mathrm{~S}$ was packed into a tin capsule with 1-5 mg of $\mathrm{V}_{2} \mathrm{O}_{5}$ to allow for a complete combustion of the sample inside the 
EA. For $\delta^{18} \mathrm{O}$ analysis, $<0.25 \mathrm{mg}$ of $\mathrm{BaSO}_{4}$ was enclosed in silver capsules with $0.2 \mathrm{mg}$ of $\mathrm{NaF}$ for reaction in the TC/EA. The $\delta^{34} \mathrm{~S}$ and $\delta^{18} \mathrm{O}$ values were reported in per mil (\%) with respect to Vienna Canyon Diablo Troilite (V-CDT) and Standard Mean Ocean Water (SMOW), respectively, and two international standards of barium sulfate NBS-127 and IAEA-SO-6 were used for calibration. The analytical precision for both $\delta^{34} \mathrm{~S}$ and $\delta^{18} \mathrm{O}$ of $\mathrm{BaSO}_{4}$ was $<0.3 \%$.

\subsection{Field Observations in White Sands, New Mexico}

The photographs of groundwater rise in the interdunes were obtained during separate field campaigns in January, May, October of 2007 and April of 2008. The field campaigns were a part of a larger geochemical study focused on determining sources of aqueous sulfate for gypsum in the White Sands dune field [24,25]. Additional photographs were obtained by A. Szynkiewicz in the late morning hours on 1 January 2010 for the frosted dunes and in the early afternoon hours on 17 January 2010 for the wet dune crests. All photographs were taken with a Canon digital camera along the southern loop of the Alkali Flat Trail in the White Sands National Monument. A standard digital thermometer was used to assess temperature changes during the collection of photographs.

\section{Results}

\subsection{South Fork of Wright Valley, Antarctica}

All quantitative and isotopic results for the South Fork catchment samples are presented in Table 1 . The acid-soluble sulfate content was variable in soils $(0.13-0.89 \mathrm{wt} \% \mathrm{~S})$, but significantly higher than the sulfide content $(<0.01 \mathrm{wt} \% \mathrm{~S})$. Note that no measurable quantities of $\mathrm{Ag}_{2} \mathrm{~S}$ for elemental $\mathrm{S}$ and acid-volatile $\mathrm{S}$ phases were obtained during Steps 1 and 2 of sulfur sequential extraction. The soil sulfate showed wider variation of $\delta^{34} \mathrm{~S}$ $\left(+15.8 \%\right.$ o to $+32.5 \%$ ) compared to smaller ranges of $\delta^{18} \mathrm{O}(-8.9 \%$ o to $-4.1 \%)$. The highest $\delta^{34} \mathrm{~S}$ values of sulfate were observed near the Don Juan Pond site $(+27.1 \%$ to $+32.5 \%$ ), compared to lower values further uphill along the South Fork $(+15.8 \%$ to $+23.4 \%)$. In contrast, the $\delta^{34} \mathrm{~S}$ of sulfide showed significantly lower and consistent values across the studied area $\left(-0.6 \%\right.$ to $+3.3 \%$ ) . We analyzed these new $\delta^{34} S$ results for sulfides (Table 1$)$ in context with previously published data on oxygen isotope composition $\left(\delta^{18} \mathrm{O}\right)$ of Antarctic snow/ice (e.g., [8,30,31]) in Figure 2 to determine the isotope composition of sulfide-derive sulfate for the South Fork bedrock. We assumed that the majority of sulfide derived from the Ferrar Dolerite and Granitic Basement Complex bedrock, the main rock types in this portion of the McMurdo Dry Valley, which comprised the majority of the detrital grains. The latter was homogenized with secondary mineral phases during sample preparation (grinding to fine-grained fraction) for sulfur sequential extraction.

\subsection{White Sands, New Mexico}

During the winter of 2006/2007, the groundwater table rose above the White Sands interdunes (Figure 3A,B), which led to water ponding within the interdunes until May 2007. This produced erosion of interdunes and deposition of new, thin gypsum crusts on top of older cross-bedding strata. The resulting morphology is characterized by small ponding shorelines that contour along the dune lee slopes and interdunes (Figure 3B-D). After the groundwater table decreased and water evaporated from the interdunes, the newly formed gypsum crusts underwent wind erosion that re-exposed the older, cemented surfaces of the interdunes with cross-bedding strata (Figure 3D). 


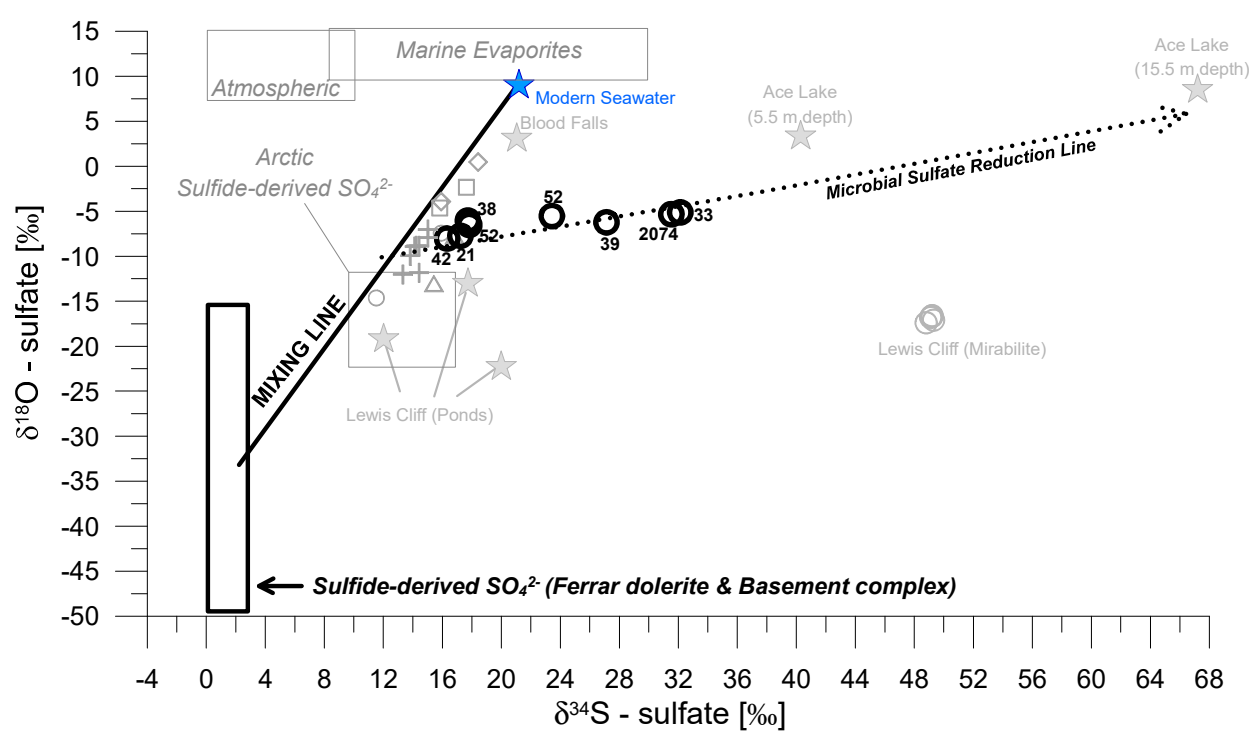

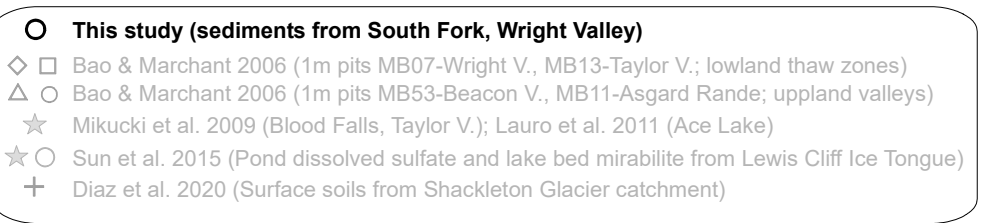

Figure 2. Comparison of $\delta^{34} \mathrm{~S}$ and $\delta^{18} \mathrm{O}$ in secondary sulfate salts between the South Fork of Wright Valley (this study, black circles) and other areas of Antarctica (light gray symbols) studied by previous investigators [7-9,31]. Because of small isotopic variations with depth, average values are presented for sites no. 33 and 42 . The hypothetical mixing line is presented for the sulfide- and atmospheric (sea aerosols)-derived sulfate inputs for the South Fork bedrock comprised of the Ferrar Group and Precambrian basement rocks. The $\delta^{34} S$ of sulfide-derived sulfate is based on sulfur sequential extraction results (this study; Table 1 ) and $\delta^{18} \mathrm{O}$ is based on previously reported isotope compositions of surface water and groundwater $[8,30,31]$. Note that larger variation of $\delta^{18} \mathrm{O}$ in the Antarctic hydrological system precludes from more precise determination of the $\delta^{18} \mathrm{O}$ of sulfide-derived sulfate. Therefore, only $\delta^{34} \mathrm{~S}$ of sulfides is used for quantitative estimates of sulfide-derived sulfate in the studied sediments from the South Fork catchment (see Section 5.1.2 for more details).
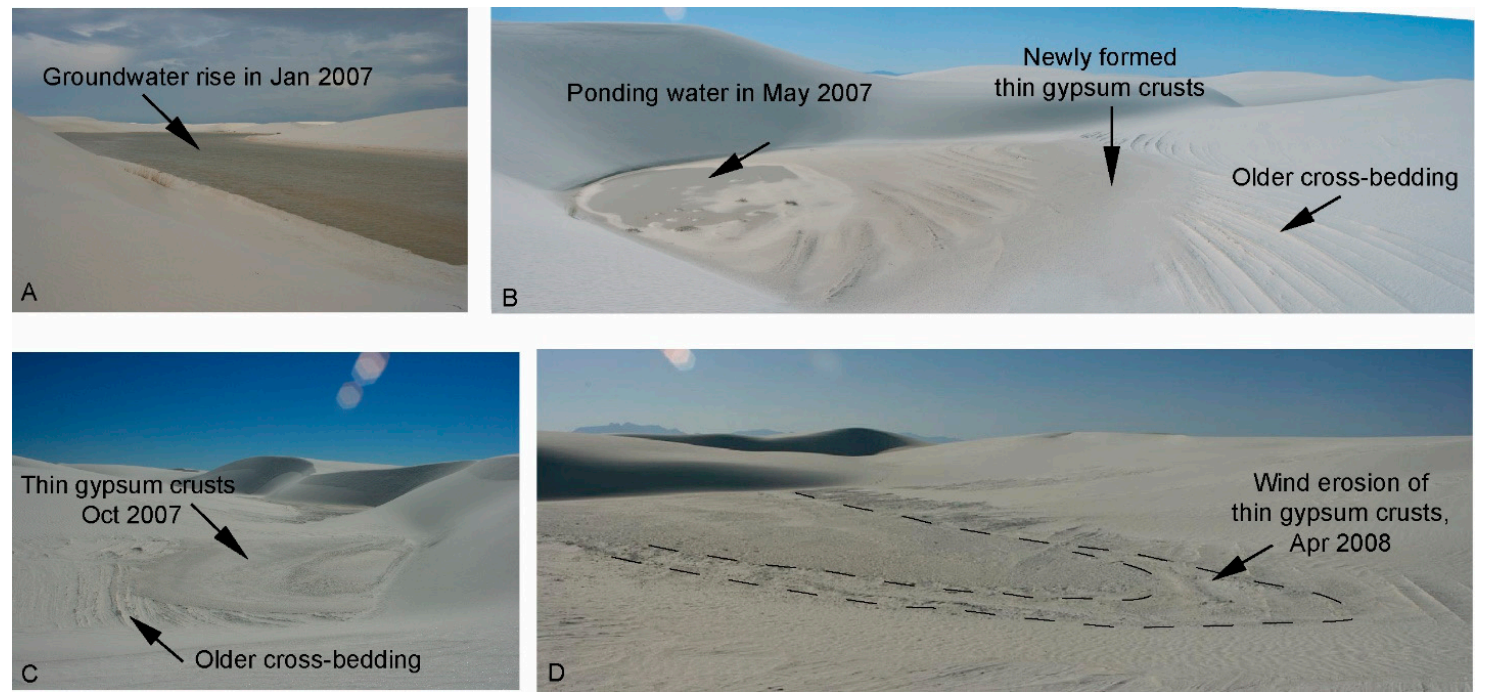

Figure 3. Surface features associated with groundwater rise in the White Sands interdunes during the winter of 2006/2007 (Photographs taken by A. Szynkiewicz). (A) ponding water in the center of White Sands dune field (January 2007). $(B, C)$ newly formed thin gypsum crusts after groundwater rise and water ponding in the interdunes (May and October 2007). (D) subsequent wind erosion of thin gypsum crusts (April 2008) exposing older cross-bedding strata preserved by previous episodes of groundwater rise. 
In early January 2012, freezing temperatures persisted during the day and night times leading to accumulation of frost (water ice) on the dune surfaces. Throughout the day, it was apparent that the frost was sublimating particularly on the windward slopes that are more exposed to sunlight (Figure 4A). In contrast, the shaded dune areas of leeward slip faces remained covered with frost throughout the day (Figure 4B,C). The frost was likely cementing the gypsum sand (Figure $4 C, D$ ). As a result, large cracks had formed along the dune crests and led to mass wasting on the leeward slip faces of the dunes (Figure 4A,C). In late January 2012 , humid and warmer conditions $\left(>15^{\circ} \mathrm{C}\right)$ led to melting of frost and small patches of snow (Figure 4E). This led to wetting of the gypsum sand along the dune crests (Figure 4D,E). In contrast, the avalanches of dry sand on dune crests are more apparent during hot summer months.

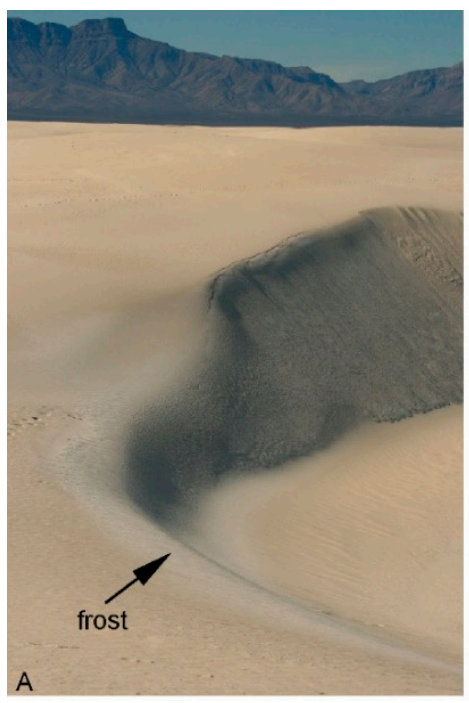

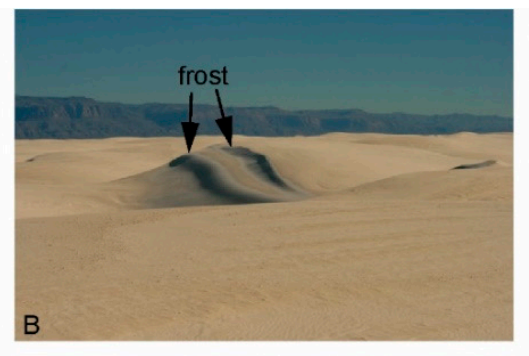

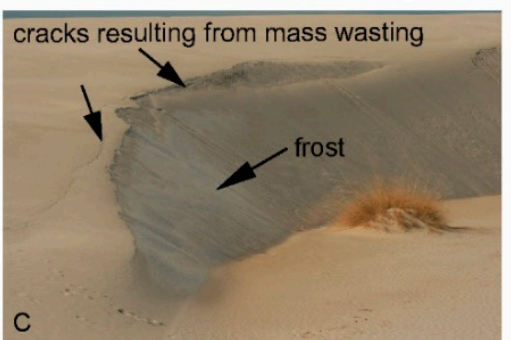

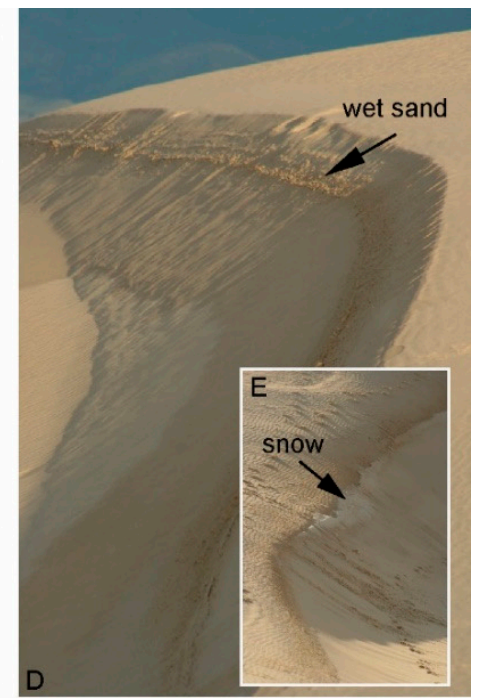

Figure 4. White Sands dunes in January of 2010 (Photographs taken by A. Szynkiewicz). (A-C) lighter- toned frost on dune crests and slip faces during freezing and dry conditions on 1 and 30 January. (D,E) snow accumulations and wetting of gypsum sand on dune crests during warmer and humid conditions on 17 January.

\section{Discussion}

In the first part of the discussion, we review existing literature to evaluate sulfate sources participating in formation of sulfate-rich soils and surficial deposits in the McMurdo Dry Valleys (MDV) of Antarctica. Then we compare our new isotopic results from the South Fork of Wright Valley to previous isotopic studies in different locales across Antarctica to quantify sulfate sources from chemical weathering in comparison to atmospheric deposition and inputs from relicts of sea and lake waters.

In the second part of the discussion, we use this knowledge and additional field observations of the White Sands gypsum dune field from two distinctive winter seasons to evaluate whether secondary hydrological processes could have participated in the formation of gypsum in the circumpolar dune fields on Mars.

\subsection{Sulfate Sources in Antarctica}

\subsubsection{Previous Studies on Antarctic Sulfates}

Elevated concentrations of secondary sulfate salts ( $<1$ to $12 \mathrm{wt} \%)$ mixed with detrital material have been reported in glacial tills and moraine deposits of the MDV (e.g., [7]). In upland valleys and older tills of $\sim 8-15 \mathrm{Ma}$, these sulfates show distinctive positive $\delta^{34} \mathrm{~S}$ values $\left(+11 \%\right.$ to $+17 \%$ ) and negative $\delta^{18} \mathrm{O}$ values $(-14 \%$ o to $-8 \%$ ) compared to slightly higher values ( $+15 \%$ o to $+19 \%$ and $-5 \%$ to $+1 \%$, respectively) in lowland thaw zones and younger moraine deposits of $\sim 3-5 \mathrm{Ma}$ (Figure 2) [7]. Similar isotope compositions of secondary sulfate salts have been recently reported for the surficial deposits of Shackleton Glacier catchment (Figure 1), a major outlet glacier of the East Antarctic Ice Sheet located 
in the Central Transantarctic Mountains [9]. While the negative $\delta^{18} \mathrm{O}$ values are typical for sulfates derived from oxidation of sulfide minerals in Arctic subglacial and proglacial environments [6], the $\delta^{34} \mathrm{~S}$ values are more positive than usually found in sulfide mineralization ( $-30 \%$ to $-10 \%$ in biogenic sulfides, $-3 \%$ to $+3 \%$ in magmatic sulfides). As a result, atmospheric deposition has been considered as a primary source of sulfates in the Antarctic surficial deposits [7,9].

Sea aerosols are common in atmospheric deposition, and have elevated $\delta^{34} \mathrm{~S}$ and $\delta^{18} \mathrm{O}$ values $(+21 \%$ and $+10 \%$, respectively); thus, atmospheric deposition could satisfactorily explain increases of the $\delta^{34} \mathrm{~S}$ and $\delta^{18} \mathrm{O}$ values in the MDV secondary sulfates (Figure 1) given the close distance to the Ross Sea. However, in order to account for sulfate with $\delta^{34} \mathrm{~S}$ values of $+11 \%$ to $+16 \%$, it has been proposed that atmospheric deposition may also carry significant amounts of sulfate from oxidation of dimethylsulfide emitted via decomposition of organic matter in the global ocean [7]. This dimethylsulfide is known to have higher $\delta^{34} \mathrm{~S}$ values of $+16 \%$ to $+24 \%$ [32]. A major challenge for this theory is that the isotope composition of dimethylsulfide-derived sulfate in the Antarctic atmosphere has not been characterized by direct measurements. Instead, most of these assumptions have been made based on bulk isotopic measurements in Antarctic ice cores and from locations that are far from Antarctica and quite distant across the Atlantic and Pacific Oceans [7]. An additional challenge is the relatively low concentrations of sulfate from dimethylsulfide oxidation measured in atmospheric precipitation over the ocean and in the Antarctic ice (5-20\%) compared to estimated higher contributions from sea aerosols (80-95\%) [32-36]. Further, sulfate forming from the oxidation of modern sulfur gases (volcanic, fossil fuel combustion) in the atmosphere is usually characterized by distinctive high $\delta^{18} \mathrm{O}$ values $(>+12 \%)$ that are not found in the sulfates from MDV sediments $(-14 \%$ to $+1 \%$ ). While slightly positive $\Delta^{17} \mathrm{O}$ values in some of these sulfates $(+0.3 \%$ to $+2 \%$ ) have been argued as the primary evidence in support of the atmospheric origin theory [7], they are in disagreement with the very negative $\delta^{18} \mathrm{O}$ values of these sulfates pointing to formation in surface glacial and/or subglacial environments.

Although the $\delta^{34} \mathrm{~S}$ of sulfate cannot satisfactorily differentiate between sea aerosols $(+21 \%)$ and dimethylsulfide (average $+20 \%$ ) contributions in the Antarctic atmospheric deposition, the secondary sulfate salts from the South Fork (this study) and other MDV locations [7] and Shackleton Glacier [9] all comprise similar ranges of $\delta^{34} S$ values $(+11 \%$ to $+19 \%$ ). These values are similar to the modern dissolved sulfate from water column of three, shallow ponds in the Lewis Cliff Ice Tongue moraine $(+12 \%,+18 \%,+20 \%$ ) [8], implying that the $\delta^{34} \mathrm{~S}$ of sulfate is uniform over a larger area, likely controlled by similar geochemical processes.

\subsubsection{Assessment of Chemical Weathering-New Isotope Data}

In addition to atmospheric deposition (e.g., sea aerosols, oxidation of dimethylsulfide and volcanic sulfur), the dissolved sulfate of terrestrial aquatic systems is commonly sourced by bedrock weathering via oxidation of sulfide minerals and/or dissolution of sedimentary (marine) evaporites [11]. Sedimentary evaporites are not present in the MDV, thus the main contributions of sulfate from the bedrock are expected to be sulfide oxidation. Using multiple isotopic approaches $\left(\delta^{18} \mathrm{O}, \Delta^{17} \mathrm{O}, \delta^{34} \mathrm{~S}\right)$, Bao and Marchant [7] suggested that up to $\sim 20-40 \%$ of sulfate contributions may come from bedrock weathering and / or volcanic emission alone. However, this has not been confirmed with in situ isotope analysis of bedrock sulfur-bearing mineralization.

Generally, weathering processes are accompanied by minor/negligible isotope fractionations (e.g., $[37,38])$. The $\delta^{34} \mathrm{~S}$ of aqueous sulfate usually closely resembles that of the initial bedrock. While the $\delta^{18} \mathrm{O}$ of sulfate is similar to that observed from evaporitic minerals, the sulfide-derived sulfate inherits the $\delta^{18} \mathrm{O}$ of snow/ice/water present during oxidation of sulfide minerals (e.g., [6]). Our new results of sulfur sequential extraction on 17 surface and near-surface sediment samples from the South Fork of Wright Valley revealed traces of bedrock sulfides $(<0.01 \mathrm{wt} \% \mathrm{~S})$ with a narrow range of $\delta^{34} \mathrm{~S},-0.6 \%$ 
to $+3.0 \%$ (Table 1). These values are consistent with igneous origin of detrital (eroded) pyrite from the local Ferrar Dolerite, one of the major rock units in MDV, with similar $\delta^{34} \mathrm{~S}$ of $-1 \%$ to $+3.0 \%$ [39]. In Figure 2, we estimated that the $\delta^{18} \mathrm{O}$ of sulfate originating from oxidation of this sulfide would vary in a wider range $(-50 \%$ to $-15 \%$; average $-32 \%$ ) because of varied $\delta^{18} \mathrm{O}$ in glacial melt waters and shallow groundwater measured in numerous locations along the Transantarctic Mountains (e.g., [8,30,31]). Many of the secondary sulfates from the South Fork sediments (this study) and other places in the MDV investigated by Bao and Marchant [7] are clustered near the theoretical mixing line for atmospheric- and bedrock sulfide-derived sulfate based on $\delta^{34} S$ versus $\delta^{18} \mathrm{O}$ values. Note that in this comparison the atmospheric endmember is likely comprised of varied proportions of sea aerosols and dimethylsulfide-derived sulfate that both have high $\delta^{34} \mathrm{~S}$ values (in average +20 to $+21 \%$; also see Section 5.1.1 for more details). Consequently, quantitative contributions of the bedrock-sourced sulfate in the South Fork sediments can be estimated using the sulfur isotope mass balance constraint:

$$
\delta^{34} \mathrm{~S}_{\text {soil sulfate }}=\mathrm{x} \cdot \delta^{34} \mathrm{~S}_{\text {sulfide-derived sulfate }}+(1-\mathrm{x}) \cdot \delta^{34} \mathrm{~S}_{\text {atmospheric sulfate }}
$$

where $x$ is an input from sulfide-derived sulfate. Accordingly, $20 \%$ of sulfate would come from bedrock weathering in the South Fork, particularly in higher elevation locations no. 21, $38,42,52$. It is noteworthy that the $\delta^{34} S$ of sulfate in these sediments was shifted (increased) by $\sim 3 \%$ to the right from the mixing line on Figure 2, suggesting subsequent increases of $\delta^{34} S$ resulting from microbial sulfate reduction (see next paragraph Section 5.1.3 for more details). If that is the case, the sulfide-derived sulfate contributions would be higher, including up to $\sim 35 \%$ in the higher elevation locations along the South Fork. Generally, these estimates fall in a similar range to the sulfide-derived sulfate contributions described by Bao and Marchant [7].

\subsubsection{Alteration of Isotopic Signatures by Microbial Processes}

Microbial sulfate reduction has been observed in modern lakes of the MDV and Ace Lake in the Vestfold Hills region (Figure 1) and led to the formation of secondary biogenic sulfides with negative $\delta^{34} \mathrm{~S}$ in the bottom sediments ( $-22 \%$ to $-2 \%$ ) and dissolved sulfate with very positive $\delta^{34} S$ values in the water column ( $+40 \%$ to $+67 \%$ ) [8,40-42]. Some older lake deposits with abundant mirabilite (sodium sulfate) found near the Lewis Cliff Ice Tongue, located $\sim 100 \mathrm{~km}$ away from MDV (Figure 1), also show distinctive positive $\delta^{34} \mathrm{~S}$ of $+48 \%$ to $+49 \%$, implying significant microbial metabolism in the past [8]. In the South Fork catchment, our sediment samples from locations 42 and 52 were collected from small pond sites that were dry at the time of sampling in 1980, but appeared to have been wet in the past. Increases in the $\delta^{34} \mathrm{~S}$ for samples from these sites are satisfactorily explained by microbial sulfate reduction (Figure 2) under former wet conditions.

The highest $\delta^{34} S$ of $+32 \%$ was observed in surface sediments collected in the peripheral parts of Don Juan Pond (Locations 33 and 2074), a main drainage area for the South Fork and parts of the adjacent Wright Glacier (Figure 1). The pond is believed to be sourced by upwelling groundwater from a regional flow system of the Wright Valley [43] and occurs at the lowest elevation along the South Fork (Figure 1B). In contrast to samples from sites 42 and 52, we did not detect any secondary biogenic sulfides with distinctive negative $\delta^{34} \mathrm{~S}$ values in the pond sediments that would point to in situ microbial sulfate reduction as observed in larger lakes of the Wright Valley ( $-21 \%$ to $-4 \%$ in Lake Hoare; [40]). Instead, we observed typical igneous values of $\delta^{34} \mathrm{~S}(0 \%$ to $+3 \%$ ) as in the detrital pyrite $(-1 \%$ o to $+3 \%$ ) from past glacial erosion of the Ferrar Dolerite [39]. Therefore, it is likely that the sulfate with higher $\delta^{34} S$ in the Don Juan Pond sediments was transported from a different location in the South Fork catchment and/or Wright Glacier. Alternatively, microbial sulfate reduction might be occurring in deeper sediments given that the brine underlying Don Juan Pond is depleted in dissolved sulfate even at depths of $75 \mathrm{~m}(<100 \mathrm{mg} / \mathrm{L})$ compared to elevated calcium and chloride concentrations $(40,000-120,000 \mathrm{mg} / \mathrm{L})$ [30]. 


\subsubsection{Additional Alteration Processes-Oxygen Isotope Exchange}

The comparison of $\delta^{34} \mathrm{~S}$ and $\delta^{18} \mathrm{O}$ of sulfate from different locations of Antarctica (Figures 1 and 2) reveals a strong effect of microbial sulfate reduction on $\delta^{34} S$ (very positive values) in lakes and ponds but rather insignificant increases of $\delta^{18} \mathrm{O}$ (usually negative values), which should also accompany this microbial process. The latter might result from oxidation of hydrogen sulfide $\left(\mathrm{H}_{2} \mathrm{~S}\right)$, derived from microbial sulfate reduction, in the presence of lake water with negative $\delta^{18} \mathrm{O}$ originating from ice/snow melt (e.g., Ace Lake data in Figure 2). Alternatively, the longer residence time of sulfate in lake and/or glacial environments may lead to its subsequent oxygen isotope exchange with water. For example, the dissolved sulfate from the Blood Falls subglacial outflow in the Taylor Valley is believed to be a relict of seawater from past marine transgressions into the MDV during the late Miocene $[31,44]$. While the $\delta^{34} \mathrm{~S}$ of Blood Falls is identical to modern seawater $(+21 \%)$, the $\delta^{18} \mathrm{O}$ of sulfate is lower $(+3 \%)$ and accompanied by water with more negative $\delta^{18} \mathrm{O}(-40 \%)$ compared to modern seawater ( $+9 \%$ sulfate; $0 \%$ seawater) [31]. Mixing of snow /ice meltwater with paleo-seawater is likely responsible for the negative $\delta^{18} \mathrm{O}$ of Blood Falls water. Additionally, Mikucki et al. [31] suggested that lowering of $\delta^{18} \mathrm{O}$ in the dissolved sulfate of Blood Falls may be related to catalytic sulfur cycle facilitated by microbial processes that leads to a subsequent oxygen isotope exchange between sulfur intermediates and subglacial water with very negative $\delta^{18} \mathrm{O}$ values $(-40 \%)$. Given that the relict seawater of Blood Falls might be very old ( $3-5 \mathrm{Ma}$ ), it is also possible that abiotic oxygen isotope exchange between sulfate and water is additionally responsible for lowering of the $\delta^{18} \mathrm{O}$ in sulfate. Although this exchange is extremely slow at low temperatures, a near complete oxygen isotope exchange would be expected after $3-5$ Ma years $[45,46]$. The latter is consistent with the timing of marine transgressions into the MDV (late Miocene) that could have provided sulfate with seawater. Generally, the measured difference of $43 \%$ between $\delta^{18} \mathrm{O}$ of sulfate and $\delta^{18} \mathrm{O}$ of subglacial water in Blood Falls [31] is in good agreement with the expected difference of $35-40 \%$ for complete oxygen isotope exchange at near freezing temperatures [45].

Although $\delta^{18} \mathrm{O}$ of sulfate cannot differentiate between abiotic and biotic processes of oxygen isotope exchange, the distinctive low $\delta^{18} \mathrm{O}$ of sulfate observed in Antarctic surface environments might be a good tracer of sulfate contributions from older subglacial brines containing relicts of sea or lake waters. It is noteworthy that the younger (3-4 Ma) glacial moraine deposits in lowland thaw zones of the Taylor and Wright glaciers studied by Bao and Marchant [7] have $\delta^{34} \mathrm{~S}$ and $\delta^{18} \mathrm{O}$ of secondary sulfate $(+15 \%$ to $+19 \%$ and $-5 \%$ to $+1 \%$, respectively) that are more similar to the Blood Falls subglacial outflow ( $+21 \%$ and $+3 \%$, respectively) [31], implying significant sulfate input from relict seawater. In contrast, older (8-15 Ma) moraine deposits of upland valleys (Figure 1), with no evidence of past marine transgressions, showed lower $\delta^{34} \mathrm{~S}$ and $\delta^{18} \mathrm{O}$ values $(+11 \%$ to $+17 \%$ and $-14 \%$ o to $-8 \%$, respectively) suggesting more contributions $(\sim 40-50 \%)$ from bedrock sulfide weathering (Figure 2). While $\delta^{34} S$ alone cannot definitely distinguish between sulfate from relict seawater and atmospheric deposition (e.g., modern sea aerosols, dimethysulfide oxidation) because of overlapping isotopic compositions, the $\delta^{18} \mathrm{O}$ of sulfate appears to be a better tracer because of lower $\delta^{18} \mathrm{O}$ resulting from oxygen isotope exchange in the subglacial environments. This, in turn, better explains unusually positive $\delta^{34} \mathrm{~S}$ and negative $\delta^{18} \mathrm{O}$ of the Antarctic sulfates than the previously proposed sole contributions of sulfate from dimethylsulfide-derived sulfate of atmospheric origin. Note that the dimethylsulfide-derived sulfate is significantly lower in atmospheric deposition $(<1-2 \mathrm{mg} / \mathrm{L} ;[32,35])$ compared to higher sulfate concentrations in subglacial outflows such as Blood Falls ( 5000 mg/L; [31]) and modern lakes (< 100 mg/L; [47]).

\subsubsection{Summary of Sulfate Sources in Antarctica}

Our regional comparison of $\delta^{34} \mathrm{~S}$ and $\delta^{18} \mathrm{O}$ of sulfate salts in Antarctic environments using new and previously published data (Figure 2) suggests measurable contributions of sulfate from in situ sulfide oxidation in the bedrock. This is in contrast to previous studies 
suggesting atmospheric deposition as a main (or sole) source for the secondary sulfate salts in Antarctica. Additional sulfate inputs could have arisen from subglacial brines derived by relicts of seawater and/or lake (pond) settings influenced by microbial sulfate reduction particularly in lowland thaw zones. Based on the $\delta^{34} S$ of bedrock sulfides in the South Fork catchment (Table 1), sulfide weathering may contribute up to $20-50 \%$ of sulfate in the MDV lowland thaw zones and upland valleys, despite relatively low sulfide contents in the bedrock $(<0.01 \mathrm{wt} \% \mathrm{~S})$ currently. Most likely, the prevailing dry conditions for thousands to millions of years have effectively accumulated secondary, sulfate-enriched weathering products in surface environments.

However, an important question remains about the actual contributions of sulfate from atmospheric deposition (sea aerosols, dimethylsulfide oxidation) and relicts of sea or lake waters trapped in subglacial environments. This cannot be easily quantified based on the isotope composition of sulfate using existing datasets (Figure 2) with rather random spatial distributions of sampling sites and limited bedrock analysis for $\delta^{34} \mathrm{~S}$. Additional difficulty arises from overlapping isotopic compositions in the atmospheric (sea spray: $+21 \%$; dimethylsulfide oxidation: average $+20 \%$ ) and glacial (relict seawater $+21 \%$ ) sulfate endmembers. Given that relict seawater has elevated sulfate concentrations, we suggest that the atmospheric contributions of sulfate in the Antarctic lowland thaw zones might be smaller than previously thought [7-9]. Future studies would benefit from similar isotope analyses on sediment samples collected along distinctive topographic gradients, particularly at higher elevations that could improve quantification of sulfate inputs from atmospheric deposition compared to modern lowland thaw zones more affected by subglacial and lacustrine processes.

\subsection{Possible Formation Mechanisms for Sulfate in the Martian North Polar Region}

\subsubsection{Evaluation of Aqueous Sulfate Sources}

Terrestrial studies evaluating the sulfur cycle in the Northern Hemisphere clearly point to the role of the hydrological cycle in remobilizing local sulfur endmembers that lead to the formation of secondary sulfates in surficial sediments and soils (e.g., [11-13]). A similar conclusion can be drawn for polar dry settings of the Southern Hemisphere based on our new results and comparisons (Figure 2). Climate controls the extent of aqueous sulfate that is transported to the global ocean via streams and rivers (wet conditions) or is temporally stored in surficial deposits (dry conditions). Conversely, bedrock weathering, atmospheric deposition, and in some cases hydrothermal activity participate in the overall aqueous sulfate budget. Depending on the size of the sulfur reservoir at a given location, the sulfate contributions from these three sources change respectively. For example, elevated sulfate concentrations ( 100-2000 mg/L) are usually found in aqueous systems that are in closer proximity to bedrock enriched in sulfur minerals (sulfides, sulfates) and/or modern hydrothermal vents with increased sulfur emissions (hydrogen sulfide, sulfur dioxide). Conversely, sulfate concentrations in Earth's atmosphere are relatively low $(<\sim 1-2 \mathrm{mg} / \mathrm{L})$ due to the dilution effect and rapid mixing of air masses, but measurable increases of sulfate from sea aerosols are evident in precipitation along modern coastlines and from hydrothermal emissions near active volcanic centers $(<\sim 10 \mathrm{mg} / \mathrm{L})$.

The gypsum-rich circumpolar dune fields at Olympia Undae on Mars are distant from known volcanic centers, thus any contribution of sulfate from direct hydrothermal activity either via emission of sulfur-rich gasses or formation of sulfur-rich ores is unlikely. Also, atmospheric sea aerosols are improbable sources because evidence for a past global ocean on Mars is not convincing [48], and if an ocean had been present, it likely did not extend as far north as Olympia Undae. In this context, the only reasonable sulfate sources would be atmospheric deposition of oxidized volcanic sulfur gases from global air circulation $[10,49,50]$ and weathering of bedrock sulfur-bearing phases from sulfide oxidation and/or dissolution of sulfate minerals and amorphous phases [5,12,51,52].

The circumpolar dunes and layered sand deposits underlying the north polar ice cap are mainly comprised of basaltic sand [1]. Although without in situ measurements 
the exact sources and types of sulfur-bearing minerals/phases in the basaltic sand will remain speculative, the best candidates would be sulfide and sulfate minerals and/or sulfur-rich amorphous phases from past magmatic/hydrothermal activities and secondary aqueous alterations that occurred prior to wind erosion and final deposition of basaltic sand in the north polar depression. A variety of secondary Ca-Mg-Fe- $\mathrm{K}$ sulfate minerals are abundant in Martian sedimentary rocks ( 10-30 wt\% SO 3 ; e.g., [53-56]) with locally elevated sulfide (pyrrothite, pentlandite, chalcopyrite) contents as measured in Gale crater ( 0.3-1 wt\%; [57]) and Martian meteorites ( 0.2-1 wt\%; e.g., [58-61]). As a result, Martian dust appears to be enriched in sulfate minerals globally (up to $\sim 8 \mathrm{wt} \% \mathrm{SO}_{3}$; e.g., [62-65]). Further, Fishbaugh et al. [5] and Rampe et al. [52] favor oxidation of Fe-rich sulfides as the source of sulfates at Olympia Undae and Gale crater, respectively. Since the northern circumpolar dune fields appear to contain mainly gypsum, we speculate that the main sulfate sources would be from both sulfide oxidation and acidic atmospheric deposition of volcanic gases from global circulation. Both of these sources involve formation of sulfuric acid that would dissolve basaltic sand and release calcium (Ca) from Ca-rich pyroxene for subsequent gypsum precipitation (e.g., [5]). In contrast, if re-dissolution of the initial sulfate minerals and other sulfur-rich phases, containing a variety of cations including $\mathrm{Ca}$, $\mathrm{Mg}$, $\mathrm{Fe}$, and $\mathrm{K}$, in the basaltic sand was important, larger mineralogical variations should be apparent in the circumpolar dunes.

\subsubsection{Modern Water Ice and Dune Crests}

Within the Olympia Undae dune field, gypsum concentrations appear to be higher along dune crests than in the interdune areas $[1,66]$ and the gypsum appears to be $\sim 20-30 \%$ more abundant at the primary dune crests than the secondary dune crests [67]. Given that water activity would be needed to form gypsum, the dunes at Olympia Undae present an intriguing puzzle because dune crests are usually the driest portions of terrestrial dune fields. Under current dry conditions on Mars, there is no surface evidence for any recent ice melting at the north polar ice cap [2,3]. However, there is evidence for seasonal formation of frost comprised of carbon dioxide and water ice covering large surface areas of dunes and the ice cap during winter months [68,69].

Large scale accumulations of frost (mainly water ice) are also common on the White Sands gypsum dunes during the winter season. Our field observations in early January 2012 suggest that this frost usually undergoes rapid sublimation triggered by sunlight. However, the shaded portions of the White Sands dune crests effectively retained the frost on the leeward slip faces, and in some cases patches of snow, during daytime (Figure 4). We attribute this to reduced exposure of the shaded dune crests to sunlight and prevailing near freezing temperatures during the day. Additionally, warmer conditions $\left(\sim 15^{\circ} \mathrm{C}\right)$ in late January 2012 led to additional moisture from melting ice and snow being retained in these parts of the dune crests, causing visible wetting of the sand and weak cementation by reprecipitating gypsum crystals (Figure 4D). If similar processes have occurred seasonally in the circumpolar dunes on Mars, the slip faces of dune crests with basaltic sand containing sulfide minerals would be the best places to accumulate secondary sulfates from in situ chemical weathering because of longer exposures to water ice and moisture. Under these conditions, any atmospheric sulfate deposited on the Olympia Undae dune field would mix with the weathering products accumulating on dune crests and contribute to precipitation of secondary sulfate minerals along the dune crests. While in large part hypothetical, this model of gypsum formation is consistent with localized increases in gypsum as a secondary sulfate a few $\mathrm{cm}$ below the surface in Antarctic surficial deposits [70,71]. Further, our model suggests in some cases equal proportions of secondary sulfates sourced by in situ sulfide oxidation and atmospheric deposition under polar dry conditions (see Sections 5.1 and 5.2 for more details).

It should be kept in mind, however, that the above formation process has a clear disadvantage for applications to modern Mars with liquid water currently being unstable on the surface. Conversely, liquid water would be needed to accumulate (concentrate) 
sulfate from atmospheric deposition and chemical weathering based on the sulfur cycle in the terrestrial analog sites from Antarctica and White Sands.

\subsubsection{Past Groundwater Rise and Interdunes}

Alternatively, the gypsum could have formed under past wetter conditions prior to formation of the circumpolar dunes around the north polar ice cap. This might have occurred under different climate conditions in the past when liquid water was stable on the surface of Mars. It has been suggested that the basaltic sand for the circumpolar dune fields originated from wind erosion of thick layers of sand deposits (basal unit) underlying the ice cap [72-76]. The basal unit is likely a large paleoerg deposit with well-preserved eolian cross-strata (e.g., [77]) that is enriched in gypsum [2,3]. Upper portions of the basal unit underlie the Olympia Undae dune field $[1,5]$ and are characterized by distinctive white surfaces mainly exposed in the interdune areas (Figure 5A-D). These white surfaces show spectral signatures for gypsum, but in lower concentrations than on the dune crests. The latter could be a result of grain size effects [1,5], in addition to the possibility that some gypsum may have formed more recently on dune crests as discussed in the previous paragraph. Initial analysis by Fishbaugh et al. [5] revealed weak water ice signatures in the Olympia Undae interdunes but it is probable that the white color is strengthened by other white evaporitic minerals (e.g., halite, anhydrite) that do not have hydration signatures.

In the eastern portion of Olympia Undae, the white surfaces with cross-strata dominate the interdunes and are accompanied by polygons and coarse-grained-like ripples (Figure 5A-C). Conversely, large white polygonal surfaces are more apparent in the western portion (Figure 5D). Interestingly, similar polygonal surfaces can be traced over large distances along the steep outcrops of the basal unit below the ice cap (Figure 5F); this supports a broad consensus that the Olympia Undea interdunes are old surface exposures of the basal unit (e.g., [75,76]). Generally, the white cross-strata do not clearly relate to the current dune field of Olympia Undae (Figure 5A), supporting the notion that this once active eolian surface has been deflated and stabilized. This surface likely caps a previous dune constructional event during formation of basal unit. This is in contrast to the White Sands dune field, where the shapes of interdune cross-strata can be correlated to the crests of current dunes (Figure 5E). As shown on Figures 3 and 5E, the White Sands interdunes are subjected to a rising groundwater table during the winter. In 2007, this led to water ponding in many of the interdune areas and deposition of new, thin gypsum crusts. While the large-scale water ponding occurs sporadically ( $\sim 60$ years prior to the winter 2006/2007), the groundwater table usually remains near the interdune surface at White Sands, thus raising the accumulation surface, which accounts for the presence and cementation of dune cross-strata by gypsum within the interdunes (Figures 3 and 5). Usually, polygonal features are associated with drying of the deflation surfaces and thermal contraction due to secondary gypsum precipitation. In contrast, we did not observe any evidence of morphological features related to more recent water ponding in the interdunes of Olympia Undae (Figure 5). 

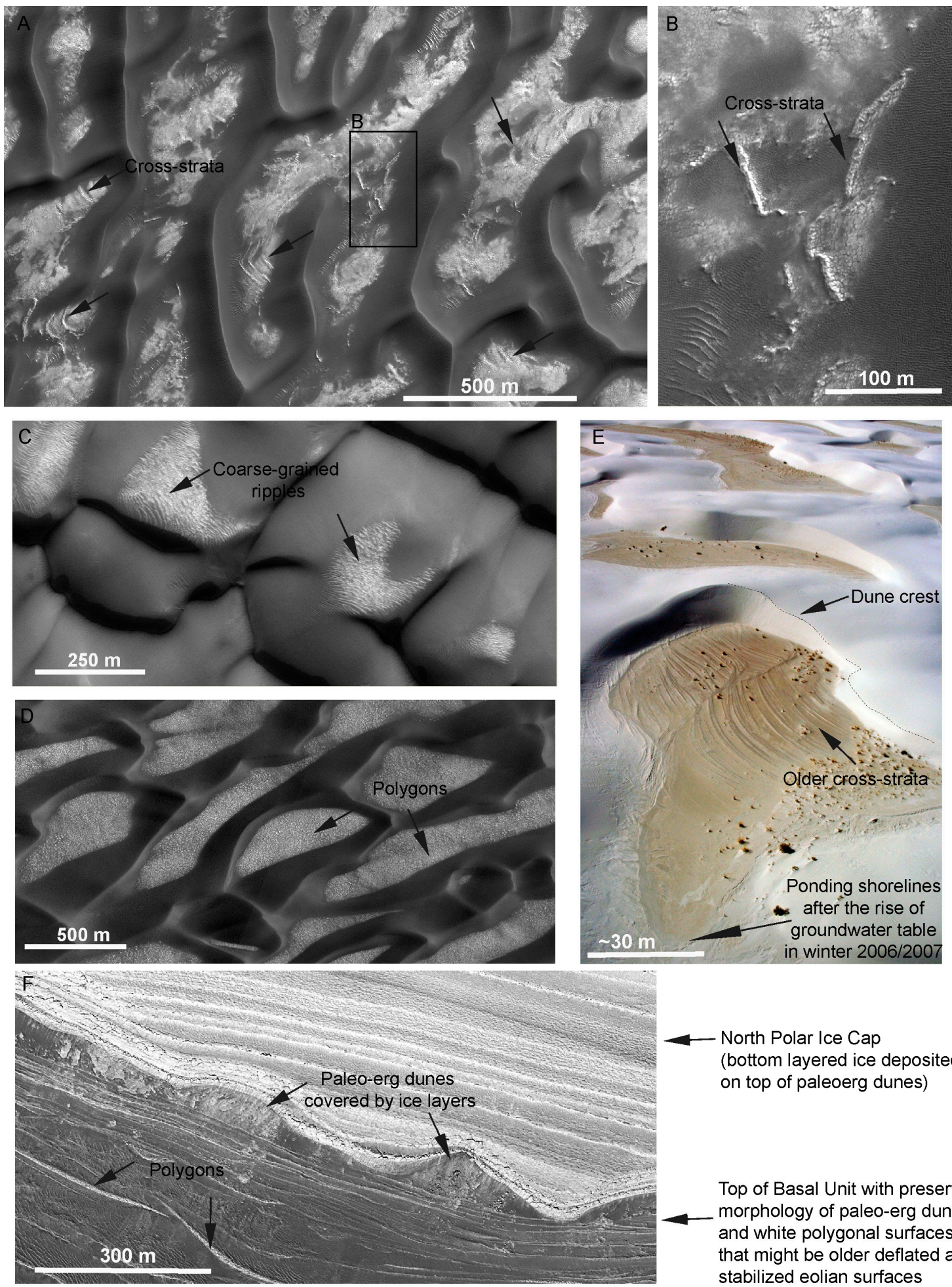

— North Polar Ice Cap (bottom layered ice deposited on top of paleoerg dunes)

Top of Basal Unit with preserved morphology of paleo-erg dunes and white polygonal surfaces that might be older deflated and stabilized eolian surfaces

Figure 5. (A,B) Portions of HiRISE image PSP_009898_2615 showing sections of the Olympia Undae dunes and bright albedo interdunes with the cross-strata left by migrating dunes (A) and polygons (B). (C) Portion of HiRISE image PSP_010049_2795 showing examples of bright albedo ripples in the interdunes of Olympia Undae. (D) Portion of HiRISE image PSP_010071_2615 showing examples of bright albedo surfaces with polygons in the interdunes of Olympia Undae. (E) Examples of the crossbedding strata and interdune gypsum crusts formed after groundwater rise in the interdunes of the White Sands Dune Field, New Mexico (Oct 2007). Image credit: A. Szynkiewicz. (F) Portion of HiRISE image PSP-010097_2650 showing the top section of the upper basal unit covered by the Ice Cap. 
One reasonable explanation for the white surfaces with gypsum spectral signatures, resembling many characteristics of the interdune cementation by rising groundwater table and evaporation within active dune field (Figures 3 and 5) is that they were formed during wetter conditions when the paleo-erg comprising the basal unit was not covered by the current ice cap and when water was stable on the surface of Mars. Any increase in past water activity would have involved leaching of sulfate from both chemical weathering of initial sulfide minerals in the basaltic sand and atmospheric deposition. Subsequent seasonal evaporation cycles within the paleo-erg interdunes would involve precipitation of evaporitic minerals, formation of polygonal surfaces, and preservation of cross-strata. This is supported overall by occurrences of secondary sulfate salts (including gypsum) from sulfide weathering and atmospheric deposition in the Arctic proglacial zones (e.g., [78]) and Antarctic surficial deposits ([7], this study). However, it is in agreement with a model of groundwater flow leading to the upward migration of sulfate-rich groundwater into White Sands Dune Field [25] and formation of secondary evaporitic gypsum crusts in the interdune areas (Figure 3). Note that in White Sands the sulfate-rich groundwater is a result of subsequent chemical weathering, mainly re-dissolution of initial gypsum present in the dunes. However, similar sulfate enrichment accompanies shallow groundwater systems within terrains with elevated sulfides undergoing oxidation to sulfate in surface and near-surface environments (e.g., [79]).

We also note that the highest gypsum concentrations are mainly detected in the western portion of the Olympia Undae dune field (e.g., [1]). One possibility is that past atmospheric deposition of volcanic sulfur might have been heterogeneous across the circumpolar dunes in the past. However, in light of our new geochemical model accounting for chemical weathering to form the gypsum at these dunes, this could be also viewed in a broader context of heterogeneous distribution of sulfide minerals in the basaltic sand of the basal unit. Regardless of whether gypsum formed more recently on dune crests or resulted from past water activity within the basal unit under different climate conditions than today, higher concentrations of gypsum should be apparent in locations with the highest sulfide concentrations in the basaltic sand.

\section{Conclusions}

Our new results on the isotope composition of secondary sulfate salts from Antarctic sediments suggest that in addition to atmospheric deposition the chemical weathering of sulfide minerals is an important source of aqueous sulfate in dry polar settings. This is consistent with similar observations in the wetter aqueous settings of the Northern Hemisphere.

Our field observations of frost, ponding water, and thin gypsum crusts on the gypsum dunes at White Sands supports reactivity of gypsum on the surface of these dunes. Despite colder temperatures on Mars, gypsum crusts could have formed through similar processes when transient liquid water or frost was available in near-surface environments at the circumpolar dunes of the north polar region on Mars. However, we recognize that these processes would not be possible under modern conditions because liquid water is currently unstable on Mars. Therefore, it is likely that the gypsum formed in the past when climatic conditions were more favorable for liquid water activity on Mars.

Our improved geochemical model of the sulfur cycle for cold settings can be applied to evaluate and update plausible sources of sulfate for gypsum precipitation in the Olympia Undae dunes. This gypsum could have formed in the past either as a result of more prolonged ice accumulations on dune crests or groundwater activity within the paleo-erg of the basal unit prior to formation of the north polar ice cap when liquid water was stable on the surface. In each of these scenarios, ice and/or water interaction with basaltic sand would have enhanced leaching of weathering products from sulfide oxidation and atmospheric deposition and resulted in formation of secondary gypsum salts.

Author Contributions: Formal analysis: A.S.; resources, A.S.; writing—original draft: A.S.; writingreview and editing: J.L.B. All authors have read and agreed to the published version of the manuscript. 
Funding: This research received no external funding.

Data Availability Statement: The data presented in this study are available in Table 1 and Figures 2-5.

Acknowledgments: We greatly thank Everett Gibson for sharing his MDV samples, Eric Smith for help with sediment grinding and sample analysis, Anthony Faiia for help with isotope analysis on the mass spectrometer, and Yasuhito Sekine for supporting publishing fee. We also appreciate assistance from Zachary Burton with the sample map in Figure 1.

Conflicts of Interest: The authors declare no conflict of interest.

\section{References}

1. Horgan, B.H.; Bell, J.F., III; Dobrea, E.Z.N.; Cloutis, E.A.; Bailey, D.T.; Craig, M.A.; Roach, L.H.; Mustard, J.F. Distribution of hydrated minerals in the north polar region of Mars. J. Geophys. Res. 2009, 114, E01005. [CrossRef]

2. Massé, M.; Bourgeois, O.; Mouélic, S.L.; Verpoorter, C.; Deit, L.L. Wide distribution and glacial origin of polar gypsum on Mars. Earth Planet. Sci. Lett. 2012, 317-318, 44-55. [CrossRef]

3. Massé, M.; Bourgeois, O.; Mouélic, S.L.; Verpoorter, C.; Deit, L.L.; Bibring, J.P. Martian polar and circum-polar sulfate-bearing deposits: Sublimation tills derived from the North Polar cap. Icarus 2010, 209, 434-451. [CrossRef]

4. Niles, P.B.; Michalski, J. Meridiani Planum sediments on Mars formed through weathering in massive ice deposits. Nature 2009, 2, 215-220. [CrossRef]

5. Fishbaugh, K.E.; Poulet, F.; Chevrier, V.; Langevin, Y.; Bibring, J.-P. On the origin of gypsum in the Mars north polar region. J. Geophys. Res. 2007, 112, E07002. [CrossRef]

6. Szynkiewicz, A.; Olichwer, T.; Tarka, R. Delineation of groundwater provenance in Arctic environment using isotopic composition of water and sulfate. J. Hydrol. 2020, 580, 124232. [CrossRef]

7. Bao, H.; Merchant, D.R. Quantifying sulfate components and their variations in soils of the McMurdo Dry Valleys, Antarctica. J. Geophys. Res. 2006, 111, D16301. [CrossRef]

8. Sun, T.; Socki, R.A.; Bish, D.L.; Harvey, R.P.; Bao, H.; Niles, P.B.; Cavicchioli, R.; Tonui, E. Lost cold Antarctic deserts inferred from unusual sulfate formation and isotope signatures. Nat. Commun. 2015, 6, 1-7. [CrossRef]

9. Diaz, M.A.; Li, J.; Michalski, G.; Darrah, T.H.; Adams, B.J.; Wall, D.H.; Hogg, I.D.; Fierer, N.; Welch, S.A.; Gardner, C.B.; et al. Stable isotopes of nitrate, sulfate, and carbonate in soils from the Transantarctic Mountains, Antarctica: A record of atmospheric deposition and chemical weathering. Front. Earth Sci. 2020, 8. [CrossRef]

10. McLennan, S.M. Geochemistry of sedimentary processes on Mars. In Sedimentary Geology of Mars; Society for Sedimentary Geology Special Publication: Tulsa, OK, USA, 2012; pp. 119-138.

11. Berner, E.K.; Berner, R.A. Global Environment: Water, Air, and Geochemical Cycles; Princeton University Press: Princeton, NJ, USA, 2012.

12. Szynkiewicz, A.; Goff, F.; Vaniman, D.T.; Pribil, M.J. Sulfur cycle in the Valles Caldera volcanic complex, New Mexico-Letter 1. Sulfate sources in aqueous system, and implications for S isotope record in Gale Crater on Mars. Earth Planet. Sci. Lett. 2019, 506, 540-551. [CrossRef]

13. Szynkiewicz, A.; Goff, F.; Faiia, A.; Vaniman, D.T. Sulfur cycle in the Valles Caldera volcanic complex, New Mexico-Letter 2. Aqueous sulfur budget and implications for hydrological transport on early Mars. Earth Planet. Sci. Lett. 2019, 506, 552-562. [CrossRef]

14. Faure, G.; Mensing, T.M. The Transantarctic Mountains: Rocks, Ice, Meteorites and Water; Springer: Dordrecht, The Netherlands, 2011.

15. Gibson, E.K.; Wentworth, S.J.; McKay, D.S. Chemical Weathering and Diagenesis of a Cold Desert Soil from Wright Valley, Antarctica: An Analog of Martian Weathering Processes. J. Geophys. Res. 1983, 88, A912-A928. [CrossRef]

16. Smith, G.J. Evaporite salts from the dry valleys of Victoria Land, Antarctica. N. Z. J. Geol. Geophys. 1965, 8, 381-382. [CrossRef]

17. Bishop, J.L.; Englert, P.A.J.; Patel, S.; Tirsch, D.; Roy, A.J.; Koeberl, C.; Böttger, U.; Hanke, F.; Jaumann, R. Mineralogical analyses of surface sediments in the Antarctic Dry Valleys: Coordinated analyses of Raman spectra, reflectance spectra and elemental abundances. Phil. Trans. R. Soc. A 2014, 372, 20140198. [CrossRef] [PubMed]

18. Marchant, D.R.; Denton, G.H.; Swisher, C.C., III. Miocene-Pliocene-Pleistocene glacial history of Arena Valley, Quartermain Mountains, Antarctica. Geogr. Ann. 1993, 75A, 269-302. [CrossRef]

19. Marchant, D.R.; Denton, G.H.; Sugden, D.E.; Swisher, C.C., III. Miocene glacial stratigraphy and landscape evoloution of the Western Asgard Range, Antarctica. Geogr. Ann. 1993, 75A, 303-330. [CrossRef]

20. Sugden, D.E.; Denton, G.H.; Marchant, D.R. Landscape evolution of the Dry Valleys, Transantarctic Mountains: Tectonic implications. J. Geophys. Res. 1995, 100, 9949-9967. [CrossRef]

21. Graf, H.F.; Feichter, J.; Langmann, B. Volcanic sulfur emissions: Estimates of source strength and its contribution to the global sulfate distribution. J. Geophys. Res. 1997, 102, 10727-10738. [CrossRef]

22. Langford, R.P. The Holocene history of the White Sands dune field and influences on eolian deflation and playa lakes. Quatern. Intern. 2003, 104, 31-39. [CrossRef] 
23. Allen, B.D. Ice age lakes in New Mexico. N. M. Mus. Nat. Hist. Sci. Bull. 2005, 28, 107-114.

24. Szynkiewicz, A.; Moore, C.H.; Glamoclija, M.; Pratt, L.M. Sulfur isotope signatures in gypsiferous sediments of the Estancia and Tularosa Basins as paleoindicators of sulfate sources, hydrologic cycle and bacterial activity. Geochim. Cosmochim. Acta 2009, 73, 6162-6186. [CrossRef]

25. Szynkiewicz, A.; Ewing, R.C.; Moore, C.H.; Glamoclija, M.; Bustos, D.; Pratt, L.M. Origin of terrestrial gypsum dunesimplications for Martian gypsum-rich dunes of Olympia Undae. Geomorphology 2010, 121, 69-83. [CrossRef]

26. Schenk, C.J.; Fryberger, S.G. Early diagenesis of eolian dune and interdune sands at White Sands, New Mexico. Sediment. Geol. 1988, 55, 109-120. [CrossRef]

27. Fenton, L.K.; Bishop, J.L.; King, S.; Lafuente, B.; Horgan, B.; Bustos, D.; Sarrazin, P. Sedimentary differentiation of aeolian grains at the White Sands National Monument, New Mexico, USA. Aeolian Res. 2017, 26, 117-136. [CrossRef]

28. Wentworth, S.J.; Gibson, E.K.; Velbel, M.A.; McKay, D.S. Antarctic Dry Valleys and indigenous weathering in Mars meteorites: Implications for water and life on Mars. Icarus 2005, 174, 383-395. [CrossRef]

29. Mayer, B.; Krouse, H.R. Procedures for sulfur isotope abundance studies. In Handbook of Stable Isotope Analytical Techniques; de Groot, P.A., Ed.; Elsevier Science: Amsterdam, The Netherlands, 2004.

30. Harris, H.J.H. Hydrology and hydrogeochemistry of the South Fork, Wright Valley, Southern Victoria Land, Antarctica. Ph.D. Thesis, University of Illinois at Urbana-Champaign, Champaign, IL, USA, 1981.

31. Mikucki, J.A.; Pearson, A.; Johnston, D.T.; Turchyn, A.V.; Farquahar, J.; Schrag, D.P.; Anbar, A.D.; Priscu, J.C.; Lee, P.A. A contemporary microbially maintained subglacial ferrous “Ocean”. Science 2009, 324, 397-400. [CrossRef]

32. McArdle, N.C.; Liss, P.S. Isotopes and atmospheric sulphur. Atmos. Environ. 1995, 29, 2553-2556. [CrossRef]

33. Calhoun, J.A.; Bates, T.S.; Charlson, R.J. Sulfur isotope measurements of submicrometer sulfate aerosol particles over the Pacific Ocean. Geophys. Res. Lett. 1991, 18, 1877-1880. [CrossRef]

34. Legrand, M.; Saigne, C.F. Feniet-Saigne Methane sulfonic acid in south polar snow layers: A record of strong El Nino. Geophys. Res. Lett. 1991, 18, 187-190. [CrossRef]

35. Patris, N.; Delmas, R.J.; Jouzel, J. Isotopic signatures of sulfur in shallow Antarctic ice cores. J. Geophys. Res. 2000, 105, 7071-7078. [CrossRef]

36. Ohno, H.; Igarashi, M.; Hondoh, T. Characteristics of salt inclusions in polar ice from Dome Fuji, East Antarctica. Geophys. Res. Lett. 2006, 33, L08501. [CrossRef]

37. Krouse, H.R.; Grinenko, V.A. Stable Isotopes: Natural and Anthropogenic Sulphur in the Environment; John Willey \& Sons: Hoboken, NJ, USA, 1991.

38. Clark, K.I.; Fritz, P. Environmental Isotopes in Hydrogeology; Lewis Publishers: New York, NY, USA, 1997 ; p. 328.

39. Hagen, E.H. Geochemical studies of Neogene till in the Transantarctic Mountains; Evidence for an extraterrestrial component. MSc Thesis, Department of Geology and Mineralogy, The Ohio State University, Columbus, OH, USA, 1988.

40. Bishop, J.L.; Lougear, A.; Newton, J.; Doran, P.T.; Froeschl, H.; Trautwein, A.X.; Körner, W.; Koeberl, C. Mineralogical and geochemical analyses of Antarctic sediments: A reflectance and Mössbauer spectroscopy study with applications for remote sensing on Mars. Geochim. Cosmochim. Acta 2001, 65, 2875-2897. [CrossRef]

41. Bishop, J.L.; Anglen, B.L.; Pratt, L.M.; Edwards, H.G.M.; Des Marais, D.J.; Doran, P.T. A spectroscopy and isotope study of sediments from the Antarctic Dry Valleys as analogs for potential paleolakes on Mars. Int. J. Astrobiol. 2003, 2, 273-287. [CrossRef]

42. Saxtno, M.A.; Samarkin, V.A.; Schutte, C.A.; Bowles, M.W.; Madigan, M.T.; Cadieux, S.B.; Pratt, L.M.; Joye, S.B. Biogeochemical and 16S rRNA gene sequence evidence supports a novel mode of anaerobic mathanotrophy in permanently ice-covered Lake Fryxell, Antarctica. Limnol. Oceanogr. 2016, 61, S119-S130. [CrossRef]

43. Toner, J.D.; Catling, D.C.; Sletten, R.S. The geochemistry of Don Juan Pond: Evidence for a deep groundwater flow system in Wright Valley, Antarctica. Earth Planet. Sci. Lett. 2017, 474, 190-197. [CrossRef]

44. Lyons, W.B.; Mikucki, J.A.; German, L.A.; Welch, K.A.; Welch, S.; Gardner, C.B.; Tulaczyk, S.M.; Pettit, E.C.; Kowalski, J.; Dachwald, B. The geochemistry of englacial brine from Taylor Glacier, Antarctica. J. Geophys. Res. Biogeosci. 2019, 124, 633-648. [CrossRef]

45. Lloyd, R.M. Oxygen isotope behavior in the sulfate-water system. J. Geophys. Res. 1968, 73, 6099-6110. [CrossRef]

46. Chiba, H.; Sakai, H. Oxygen isotope exchange rate between dissolved sulfate and water at hydrothermal temperature. Geochim. Cosmochim. Acta 1985, 49, 993-1000. [CrossRef]

47. Lyons, W.B.; Welch, K.; Snyder, G.; Olesik, J.; Graham, E.Y.; Marion, G.M.; Poreda, R.J. Halogen geochemistry of the McMurdo dry valley lakes, Antarctica: Clues to the origin of solutes and lake evolution. Geochim. Cosmochim. Acta 2005, 69, 305-323. [CrossRef]

48. Carr, M.H.; Head, J.W. Geologic history of Mars. Earth Planet. Sci. Lett. 2010, 294, 185-203. [CrossRef]

49. Gaillard, F.; Michalski, J.; Berger, G.; McLennan, S.M.; Scaillet, B. Geochemical reservoirs and timing of sulfur cycling on Mars. Space Sci. Rev. 2013, 174, 251-300. [CrossRef]

50. Ojha, L.; Karunatillake, S.; Iacovino, K. Atmospheric injection of sulfur from the Medusae Fossae forming events. Planet. Space Sci. 2019, 179, 104734. [CrossRef] 
51. Dehouck, E.; Chevrier, V.; Gaudin, A.; Mangold, N.; Mathé, P.E.; Rochette, P. Evaluating the role of sulfide-weathering in the formation of sulfates or carbonates on Mars. Geochim. Cosmochim. Acta 2012, 90, 47-63. [CrossRef]

52. Rampe, E.B.; Ming, D.W.; Blake, D.F.; Bristow, T.F.; Chipera, S.J.; Grotzinger, J.P.; Morris, R.V.; Morrison, S.M.; Vaniman, D.T.; Yen, A.S.; et al. Mineralogy of an ancient lacustrine mudstone succession from the Murray formation, Gale crater, Mars. Earth Planet. Sci. Lett. 2017, 471, 172-185. [CrossRef]

53. Murchie, S.L.; Mustard, J.F.; Ehlmann, B.L.; Milliken, R.E.; Bishop, J.L.; McKeown, N.K.; Noe Dobrea, E.Z.; Seelos, F.P.; Buczkowski, D.L.; Wiseman, S.M.; et al. A synthesis of Martian aqueous mineralogy after 1 Mars year of observations from the Mars Reconnaissance Orbiter. J. Geophys. Res. 2009, 114, E00D06. [CrossRef]

54. Murchie, S.L.; Bibring, J.P.; Arvidson, R.E.; Bishop, J.L.; Carter, J.; Ehlmann, B.L.; Langevin, Y.; Mustard, J.F.; Poulet, F.; Riu, L.; et al. Visible to short-wave Infrared spectral analyses of Mars from orbit using CRISM and OMEGA. In Remote Compositional Analysis: Techniques for Understanding Spectroscopy, Mineralogy, and Geochemistry of Planetary Surfaces; Bishop, J.L., Moersch, J.E., Bell, J.F., III, Eds.; Cambridge University Press: Cambridge, UK, 2019; pp. 453-483.

55. Ehlmann, B.L.; Edwards, C.S. Mineralogy of the Martian Surface. Annu. Rev. Earth Planet. Sci. 2014, 42, 291-315. [CrossRef]

56. Arvidson, R.E. Aqueous history of Mars as inferred from landed mission measurements of rocks, soils, and water ice. J. Geophys. Res. Planets 2016, 121, 1602-1626. [CrossRef]

57. Vaniman, D.T.; Bish, D.L.; Ming, D.W.; Bristow, T.F.; Morris, R.V.; Blake, D.F.; Chipera, S.J.; Morrison, S.M.; Treiman, A.H.; Rampe, E.B.; et al. Mineralogy of a Mudstone at Gale Crater, Yellowknife Bay, Mars. Science 2014, 343. [CrossRef]

58. Lorand, J.-P.; Chevrier, V.; Sautter, V. Sulfide mineralogy and redox conditions in some shergottites. Meteorit. Planet. Sci. 2005, 40, 1257-1272. [CrossRef]

59. Lorand, J.-P.; Labidi, J.; Rollion-Bard, C.; Thomassot, E.; Bellucci, J.J.; Whitehouse, M.; Nemchin, A.; Humayun, M.; Farquhar, J.; Hewins, R.H.; et al. The sulfur budget and sulfur isotopic composition of Martian regolith breccia NWA 7533. Meteorit. Planet. Sci. 2020, 55, 2097-2116. [CrossRef]

60. Meyer, C. The Martian Meteorite Compendium 2017. Available online: http://curator.jsc.nasa.gov/antmet/mmc/index.cfm (accessed on 2 February 2021).

61. Chevrier, V.; Lorand, J.-P.; Sautter, V. Sulfide petrology of four nakhlites: Northwest Africa 817, Northwest Africa 998, Nakhla, and Governador Valadares. Meteor. Planet. Sci. 2011, 46, 769-784. [CrossRef]

62. Clark, B.C.; Van Hart, D.C. The salts of Mars. Icarus 1981, 45, 370-378. [CrossRef]

63. Gellert, R.; Yen, A.S. Elemental Analyses of Mars from Rovers Using the Alpha-Particle X-Ray Spectrometer. In Remote Compositional Analysis: Techniques for Understanding Spectroscopy, Mineralogy, and Geochemistry of Planetary Surfaces; Bishop, J.L., Bell, J.F., III, Moersch, J.E., Eds.; Cambridge University Press: Cambridge, UK, 2019; pp. 555-572.

64. Ojha, L.; Lewis, K.; Karunatillake, S.; Schmidt, M. The Medusae Fossae formation as the single largest source of dust on Mars. Nat. Commun. 2018, 9, 1-7. [CrossRef] [PubMed]

65. Berger, J.A.; Schmidt, M.E.; Gellert, R.; Campbell, J.L.; King, P.L.; Flemming, R.L.; Ming, D.W.; Clark, B.C.; Pradler, I.; VanBommel, S.J.V.; et al. A global Mars dust composition refined by the Alpha-Particle X-Ray Spectrometer in Gale Crater. Geophys. Res. Lett. 2016, 43, 67-75. [CrossRef]

66. Roach, L.H.; Mustard, J.F.; Murchie, S.; Langevin, Y.; Bibring, J.-P.; Bishop, J.; Bridges, N.; Brown, A.; Byrne, S.; Ehlmann, B.L.; et al. CRISM spectral signatures of the North polar gypsum dunes. In Proceedings of the Lunar Planetary Science Conference XXXVIII, League City, TX, USA, 12-16 March 2007.

67. Szumila, I.; Bishop, J.L.; Fenton, L.K.; Brown, A.J. Composition and morphology of gypsum dunes in Olympia Undae on Mars. In Proceedings of the 44th Lunar and Planetary Science Conference, The Woodlands, TX, USA, 18-22 March 2013.

68. Smith, D.E.; Zuber, M.T.; Neumann, G.A. Seasonal variations of snow depth on Mars. Science 2001, 294, 2141-2146. [CrossRef]

69. Byrne, S.; Zuber, M.T.; Neumann, G.A. Interannual and seasona behavior of martian residual ice-cap albedo. Planet. Space Sci. 2008, 56, 194-211. [CrossRef]

70. Patel, S.; Bishop, J.L.; Englert, P.; Gibson, E.K. Coordinating chemical and mineralogical analyses of Antarctic Dry Valley sediments as potential analogs for Mars. In Proceedings of the 46th Lunar and Planetary Science Conference, The Woodlands, TX, USA, 16-20 March 2015.

71. Burton, Z.F.M.; Bishop, J.L.; Englert, P.; Koeberl, C.; Gibson, E.K. Chemically active horizon in a soil pit from an intermittent pond site in the Dry Valleys Region, Antarctica and implications for soil processes on Mars. In Proceedings of the 49th Lunar and Planetary Science Conference, The Woodlands, TX, USA, 19-23 March 2018.

72. Byrne, S.; Murray, B. North polar stratigraphy and the paleo-erg of Mars. J. Geophys. Res. 2002, 107, 5044. [CrossRef]

73. Edgett, K.; Williams, R.; Malin, M.; Cantor, B.; Thomas, P. Mars landscape evolution: Influence of stratigraphy on geomorphology in the north polar region. Geomorphology 2003, 52, 289-297. [CrossRef]

74. Fishbaugh, K.E.; Head, J.W., III. Origin and characteristics of the Mars north polar basal unit and implications for polar geologic history. Icarus 2005, 174, 444-474. [CrossRef]

75. Tanaka, K. Geology and insolation-driven climatic history of Amazonian north polar materials on Mars. Nature 2005, 437, 991-994. [CrossRef]

76. Tanaka, K.; Rodriguez, J.A.P.; Skinner, A., Jr.; Bourke, M.C.; Fortezzo, C.M.; Herkenhoff, K.E.; Kolb, E.J.; Okubo, C.H. North polar region of Mars: Advances in stratigraphy, structure, and erosional modification. Icarus 2008, 196, 318-358. [CrossRef] 
77. Kocurek, G.; Ewing, R.C. Source-to-sink: An Earth/Mars cmparison of boundary conditions for eolian dune systems. SEPM Spec. Publ. 2012, 102, 151-268.

78. Cooper, R.J.; Wadham, J.L.; Tranter, M.; Hodgkins, R.; Peters, N.E. Groundwater chemistry in the active layer of the proglacial zone, Finsterwalderbreen, Svalbard. J. Hydrol. 2002, 296, 208-223. [CrossRef]

79. Nordstrom, D.K.; Alpers, C.N. Geochemistry of acid mine waters. In The Environmental Geochemistry of Mineral Deposits. Part A. Processes, Methods and Health Issues; Plumlee, G.S., Logsdon, M.J., Eds.; Society of Economic Geology: Littleton, CO, USA, 1999; Volume 6A, pp. 133-160. 